\title{
Export of detritus from eelgrass (Zostera marina) beds near Beaufort, North Carolina, USA
}

\author{
Steven D. Bach ${ }^{1}$, Gordon W. Thayer ${ }^{2} \&$ Michael W. LaCroix ${ }^{2}$ \\ 1 WAPORA, Inc., 5980 Unity Drive, Suite F, Norcross, Georgia 30071 , USA \\ ${ }^{2}$ National Marine Fisheries Service, Southeast Fisheries Center, Beaufort, North Carolina 28516, USA
}

\begin{abstract}
Eelgrass Zostera marina and shoalgrass Halodule wrightii occupy about $93 \mathrm{~km}^{2}$ within the $532 \mathrm{~km}^{2}$ estuarine system near Beaufort, North Carolina, but account for a major portion of total primary production. To estimate exchange with adjacent areas, we measured export of detritus (including live and dead seagrass blades, roots and rhizomes, macroalgal fronds, Spartina alterniflora stems, and particulate organic matter) from 2 sheltered embayment-type grass beds and an open water bed. We also estimated export from a much larger part of the estuary (Bogue Sound). Rates of export of $Z$. marina detritus from an embayment-type bed at Phillips Island ranged from 4.9 to $6.0 \mathrm{~g}$ ash-free dry weight $\mathrm{mo}^{-1} \mathrm{~m}^{-2}$ during summer 1976, equivalent to a total of 195 to $240 \mathrm{~kg} \mathrm{mo}{ }^{-1}$ for the bed, or to 456 to 558 metric tons $\mathrm{mo}^{-1}$ for the $532 \mathrm{~km}^{2}$ estuary, assuming seagrasses cover $93 \mathrm{~km}^{2}$. Rates of export of $Z$. marina from the Harkers Island (exposed) and Middle Marsh (embayment) beds were 13 and $1 \mathrm{~g}$ afdw $\mathrm{mo}^{-1} \mathrm{~m}^{-2}$, respectively, equivalent to 1200 and $112 \mathrm{t} \mathrm{mo}^{-1}$ for the whole estuary. These differences in export between embayment and open water types of seagrass beds are due to entrapment of floating detritus by embayment beds. The amount of detrital material exported from Bogue Sound was an extremely small portion of the total estimated biomass, due to influences of basin shape. When total amounts of material exported are compared with other sources it can be concluded that seagrass beds contribute important amounts of detrital material to the carbon cycle of this estuary.
\end{abstract}

\section{INTRODUCTION}

The seagrass Zostera marina (eelgrass) is a widespread and important primary producer in shallow nearshore marine environments of the United States and elsewhere (Thayer et al. 1984, Zieman 1975 , McRoy \& Helfferich 1977). Plant material produced in eelgrass beds is contributed by seagrasses themselves (Zostera marina or Halodule wrightil) and by other primary producers such as phytoplankton, benthic macroalgae and epiphtyic algae. A portion of the plant material produced within an eelgrass bed may be retained and recycled in the sediments. A portion may also be exported in the form of blades, particulate organic matter (POM), or dissolved organic matter (DOM). Detrital material exported to adjacent unvegetated areas may serve an important ecological role by providing a source of nutrition for microbes and larger detritovores. However, although the production ecology of eelgrass (Penhale 1977. Thayer et al. 1984) and various aspects of eelgrass decomposition have been studied (Josselyn \& Mathieson 1980, Kenworthy \&
Thayer 1984), little is know concerning the types and relative amount of detrital material exported (Thayer et al. 1975a, Thayer et al. 1984).

Quantitative studies of export of detrital material in coastal areas have been limited largely to Spartina alterniflora (Nixon 1980) even though the importance of detritus in these systems was hypothesized over 60 yr ago (Petersen \& Boysen-Jensen 1911, Petersen 1918). Early workers provided qualitative evidence of the importance of detritus exported from European Zostera marina beds (Ostenfeld 1908, Blegvad 1914, Petersen 1918). In the United States, studies of seagrass export have also been primarily qualitative. Marshall (1970) estimated that about $2 / 3$ to $3 / 4$ of the annual production in New England Zostera marina beds was recycled into sediments. Menzies et al. (1967), Menzies \& Rowe (1969) and Wolff (1976) provided qualitative estimates of standing crop and abundance of turtlegrass (Thalassia testudinum) blades transported to deep sea areas off the coast of North Carolina. Zieman et al. (1979) quantitatively measured rates of export of blade material from Carribean seagrass beds. Gallagher et 
al. (1984) studied the amounts and types of Zostera marina and $Z$. japonica detritus contributed to Oregon salt marshes. The study included estimates of seasonal amounts of detritus in the marsh, variation in rates of eelgrass detritus decomposition, detrital 'community' respiration rates, release and export of DOC, import rates of macrodetritus and nutrient input rates. Other than the studies by Zieman et al. (1979) and Gallagher et al. (1984) no quantitative measurements of export from seagrass beds have yet been made. The overall objective of the present study was therefore to make quantitative measurements of rates of detrital export from eelgrass beds in order to identify the types of material exported and the primary factors controlling rates of export.

The present study was conducted in the $532 \mathrm{~km}^{2}$ estuary near Beaufort, North Carolina (USA). The area includes the North and Newport River estuaries (Fig. 1). Zostera marina has been estimated to account for approximately $64 \%$ of the total primary production in this estuary (Thayer et al. 1975a, Penhale \& Smith 1977). Approximately $55 \%$ of the total production by phytoplankton, benthic algae, and $Z$. marina in a New- port River eelgrass bed was estimated to be consumed by macrofauna (Thayer.et al. 1975b). The remaining portion was available either for consumption by meiofauna, microfauna and microbes, for sedimentation, or for export to surrounding areas. In the present study, it was hypothesized that a large portion of the eelgrass produced could be exported as detritus, which could play an important trophic role in unvegetated areas. Benthic macroalgae, other seagrasses such as Halodule wrightii and microalgae were also identified as possible important sources of detritus.

The specific objectives of the present study were to estimate the amounts of detritus exported by eelgrass beds in the study area, to determine the major factors which controlled export, and to compare the rates of export with other sources of detritus. These objectives were achieved by: (1) estimating seasonal patterns and relative amounts of eelgrass and other plant material exported from a sheltered embayment bed (Phillips Island); (2) estimating and comparing rates of export of eelgrass and other plant material from an embayment type bed (Middle Marsh) and an open bed (Harkers Island); (3) measuring rates of export of eelgrass and

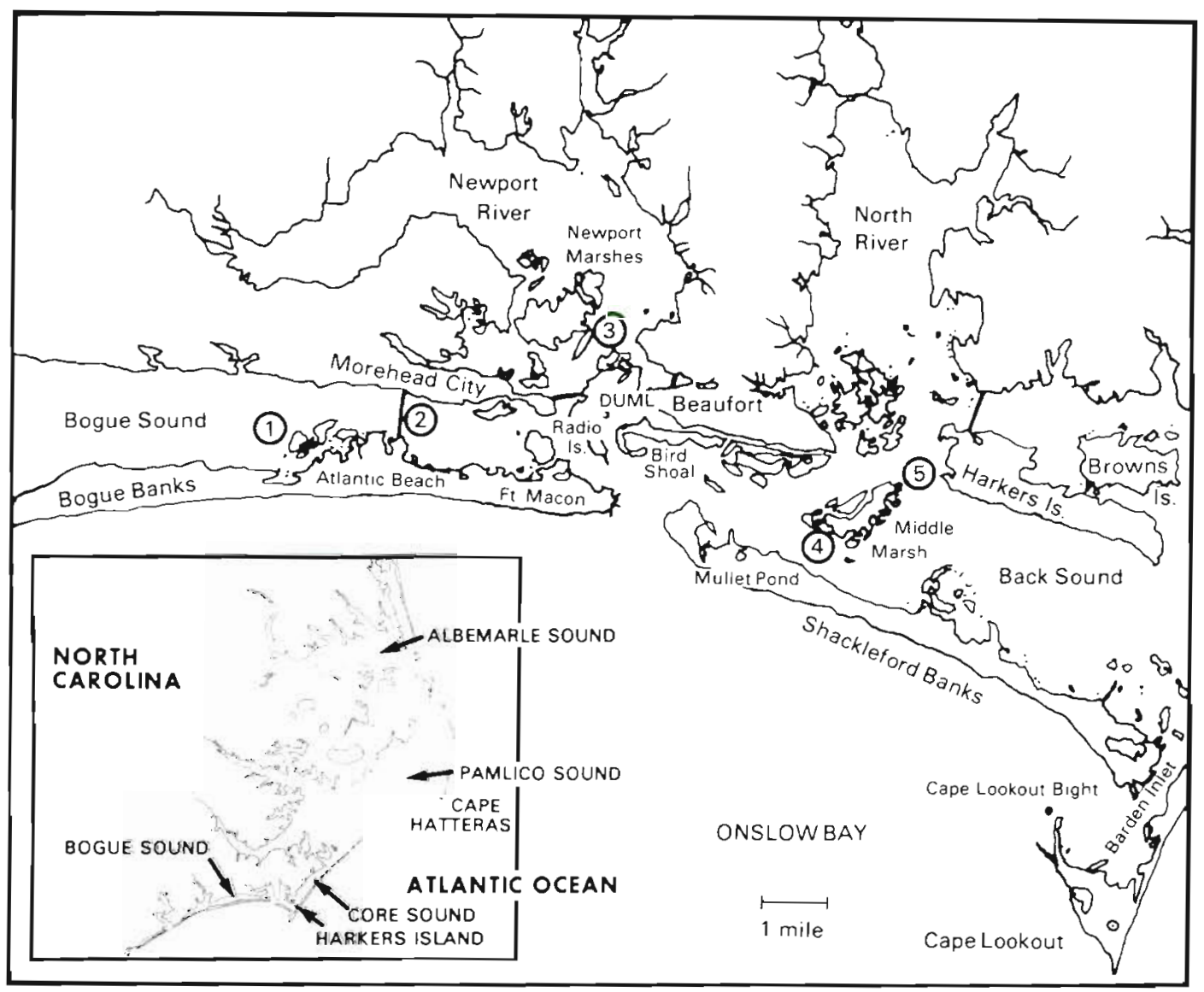

Fig. 1 The eastern North Carolina shoreline showing location of study area near Beaufort, and sites where measurements were made: (1) Drum Shoals (biomass stations for Bogue Sound); (2) Atlantic Beach Causeway Bridge; (3) Phillips Island eelgrass bed; (4) Middle Marsh eelgrass bed; (5) Harkers island eelgrass bed 
other plant material from a larger portion of the estuary (Bogue Sound); and (4) comparing the results to previous studies and to estimated amounts of export by other primary producers in the study area.

\section{MATERIAL AND METHODS}

Seasonality of export was examined by making weekly measurements of surface-drifting plant material in an eelgrass bed at Phillips Island (Fig. 1). Surface-drifting plant material was collected in floating nets $(1.0 \times 0.3 \times 0.3 \mathrm{~m})$ (Fig. 2) placed at each end of the eelgrass bed across the main axis of tidal flow (Fig. 3). Four nets (two $500 \mu \mathrm{m}$ and two $250 \mu \mathrm{m}$ mesh) were set at each end of the grass bed, and plant material was collected over a known portion of the tidal cycle. The $250 \mu \mathrm{m}$ nets were used to collect particulate organic matter (POM). Net export rates were estimated by subtracting mean amounts of plant material caught in the inflow and outflow nets and extrapolating this value to the entire tide cycle.

Rates of export were initially expressed as mg dry weight of plant materials per $\mathrm{m}^{3}$ of water that passed through the nets. Water volumes were estimated by measuring current velocities simultaneously during each collection period with one TSK flowmeter (model WA-200) placed next to each set of nets. The meters were calibrated to correct for effects of backwash produced by resistance of the collecting nets to flow. A net backwash factor was determined by measuring the difference between current readings of meters inside and outside net openings over a range of current velocities. Export rates in $\mathrm{mg}$ dry $\mathrm{wt}^{-3}$ were corrected for backwash and then converted to mg dry wt $\mathrm{m}^{-3}$ tide $^{-1}$ by extrapolation to the full tidal cycle (for the top $0.3 \mathrm{~m}$ of water column only). This was done by dividing values of export in $\mathrm{mg}$ dry $w \mathrm{t} \mathrm{m}^{-3}$ by the percentage of the total tidal volume sampled. The method assumes that the material in the upper $0.3 \mathrm{~m}$ is representative of the whole water column (total height of the water column was less than $1 \mathrm{~m}$ in both study areas)

Total tidal volume was estimated by making separate measurements of current velocities over a single complete flood and ebb tide cycle and calculating the sample period as a percentage of the total area under the tidal velocity curve (about $60 \%$ of the tidal cycle was sampled). Values in $\mathrm{mg}$ dry wt $\mathrm{m}^{-3}$ tide $^{-1}$ were multiplied by the estimated total discharge across the upper $0.3 \mathrm{~m}$ of the water column over the bed (the depth of the nets) to give $\mathrm{mg}$ dry wt tide ${ }^{-1}$. Discharge was determined separately each sampling day by combining information on tidal velocities and tabulated values of predicted tide heights. Daily rates of export were based on 4 tides $\mathrm{d}^{-1}$ and monthly rates were estimated by multiplying daily rates by the number of days in the month. Final values were expressed in $g$ ash-free dry wt (afdw) based on organic content of pooled samples for each collection. Organic content was determined by measuring weight loss of dried material at $550^{\circ} \mathrm{C}$.

From July to December 1976, export was measured by using 4 freely swinging nets. Each was loosely attached to a vertical steel pole by a ' $U$ ' bolt to allow for free horizontal and vertical movement. However, strong winds occasionally turned some of the nets around, so that after December 1976, 2 of the nets in

Fig. 2. Nitex mesh nets used to collect

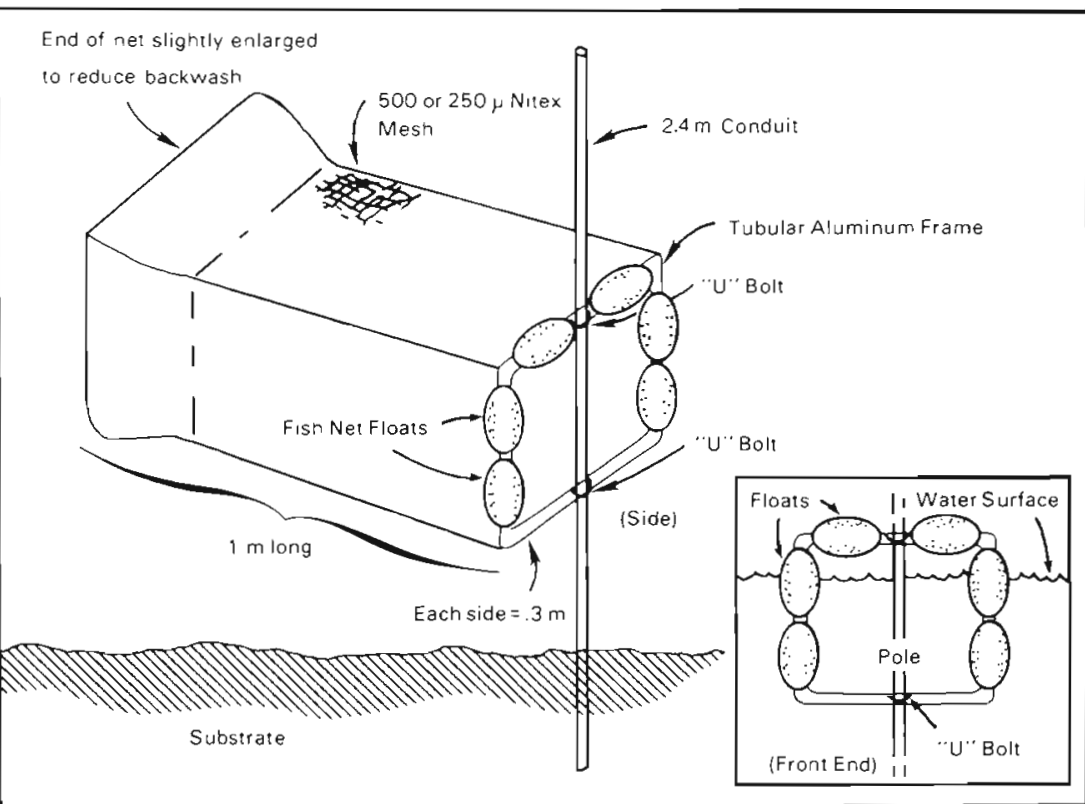
drifting plant material 


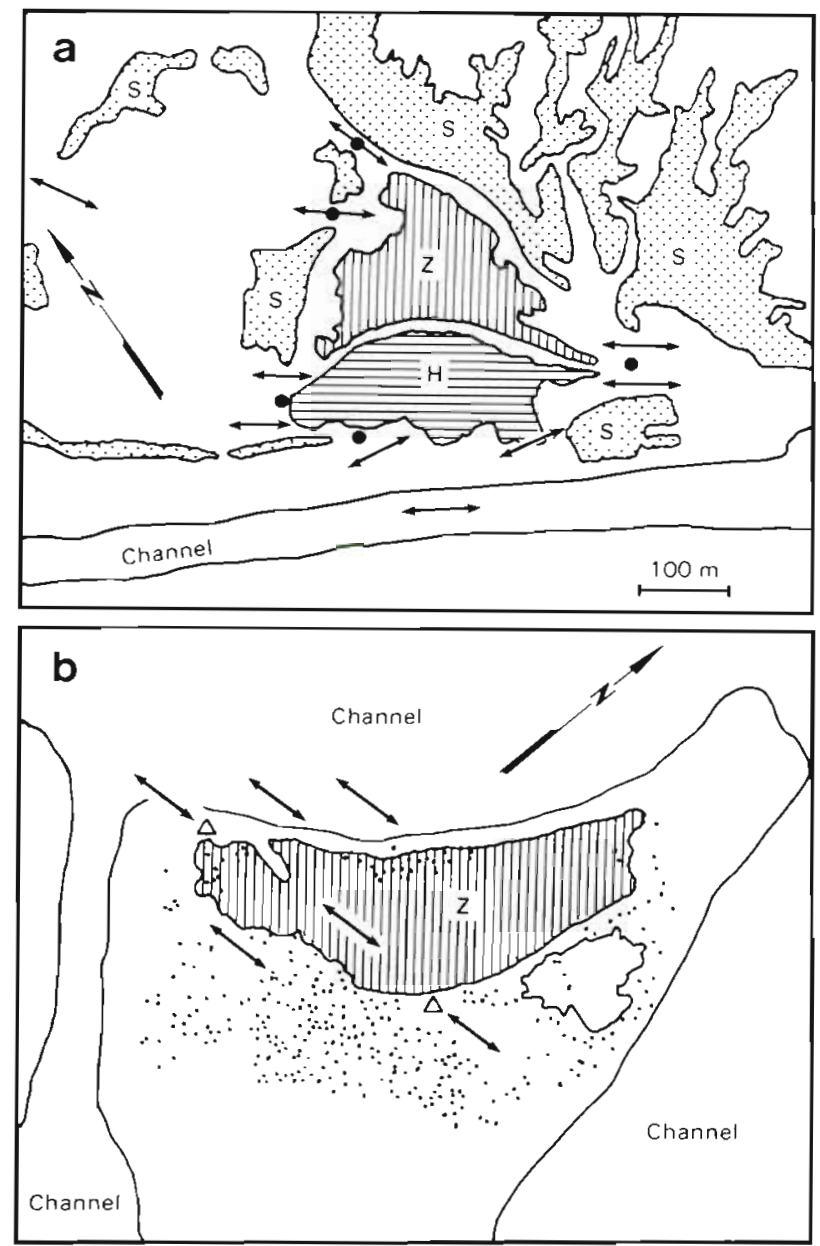

Fig 3. (a) Middle Marsh eelgrass bed. This bed is protected on 3 sides by Spartina alterniflora marsh (S), and connected to the rest of the estuary by channels and a shoal on the southern side. The bed is divided into 2 approximately equal halves the northern half being deeper with fine clay/silt sediments and very dense Zostera marina $(Z)$, and the southern half characterized by an elevated shoal of much coarser wellsorted sediments and covered almost entirely by Halodule wrightij $(\mathrm{H})$. Solid circles show positions of nets used to collect plant material being imported or exported; arrows denote observed current flows once the shoal is covered with water. (b) Harkers Island eelgrass bed. This bed is located in open water. Outline of bed determined from aerial photographs. Channels are located on all 3 sides of the bed, which is situated on a shoal just south of Harkers Island. Triangles indicate positions of replicate nets; dots indicate small

patches of seagrasses (both $H$. wrightii and $Z$. marina)

each set were held in permanent horizontal position by an aluminum frame (with free vertical movement). Material collected by fixed nets represented tidally driven export, while material collected by freely swinging nets represented wind driven export on days when wind velocities were sufficient to reverse the position of the nets. On most days, material was collected twice daily, once on ebb and once on flood tide.
Plant material was returned to the laboratory, rinsed in fresh water and frozen before sorting into fractions and weighing. Fractions included live (green) and dead (brown) Zostera marina blades and rhizomes; Halodule wrightii blades, rhizomes, and roots (pooled as 1 fraction); Spartina alterniflora stems and leaves; macroalgae; and particulate organic matter (POM) (from the $250 \mu \mathrm{m}$ nets).

The effect of bed type on export rates was determined by making measurements in 2 different kinds of eelgrass beds (open versus embayment) in the North River estuary (Fig. 3). These are the 2 primary types of seagrass beds present in this estuary, and represent the range of hydrologic conditions which might affect export. The open eelgrass bed was located just south of Harkers Island in open water, several hundred meters from the nearest land or Spartina alterniflora marsh. The eelgrass bed at Middle Marsh was enclosed on 3 sides by $S$. alterniflora and connected to the adjacent estuary by 4 channels and a large opening across a shoal area (Fig. 3). Detritus was sampled by collecting surface drifting material in replicate nets placed on the inflow and outflow sides of each bed (Fig. 3). The amount of bottom-drifting plant material was measured at these 2 locations during summer 1978 by positioning nets without floats on the bottom.

To measure export from a larger portion of the estuary, drifting plant material from Bogue Sound was collected under the Atlantic Beach causeway bridge (Fig. 1 \& 4) on ebb and flood tides. Nine nets were attached to $10 \mathrm{~m}$ lines at known intervals along the bridge. Export was extrapolated from the difference in mean amounts of plant material caught on ebb and flood tides for all sampling days (samples were taken on 14 dates between 26 July and 25 August, 1977).

For all study sites, export was also expressed as a percentage of biomass and production. Biomass data were obtained using stratified random sampling. All biomass samples were collected between June and August during 1976 (Phillips Island), 1977 (Bogue Sound) and 1978 (Harkers Island and Middle Marsh) (Fig. 1). Peak biomass for Zostera marina typically occurs between March and June in this estuary, whereas Halodule wrightii typically reaches its peak biomass in August-September. Between 20 and 45 samples were taken in each bed with a $14 \mathrm{~cm}$ diameter post hole digger. Total biomass for the eastern part of Bogue Sound was estimated from data given in Dillon (1971). Additional data on biomass were taken from Thayer et al. (1975b) and Penhale \& Smith (1977). To determine total biomass of Harkers Island and Middle Marsh eelgrass beds, biomass estimates for each bed were combined with estimates of horizontal extent made from aerial photographs.

Leaf production was measured using a technique 
Fig. 4. Location of eelgrass beds in Bogue Sound at which biomass samples were collected during summer of 1977 . Numbers denote approximate location of each bed

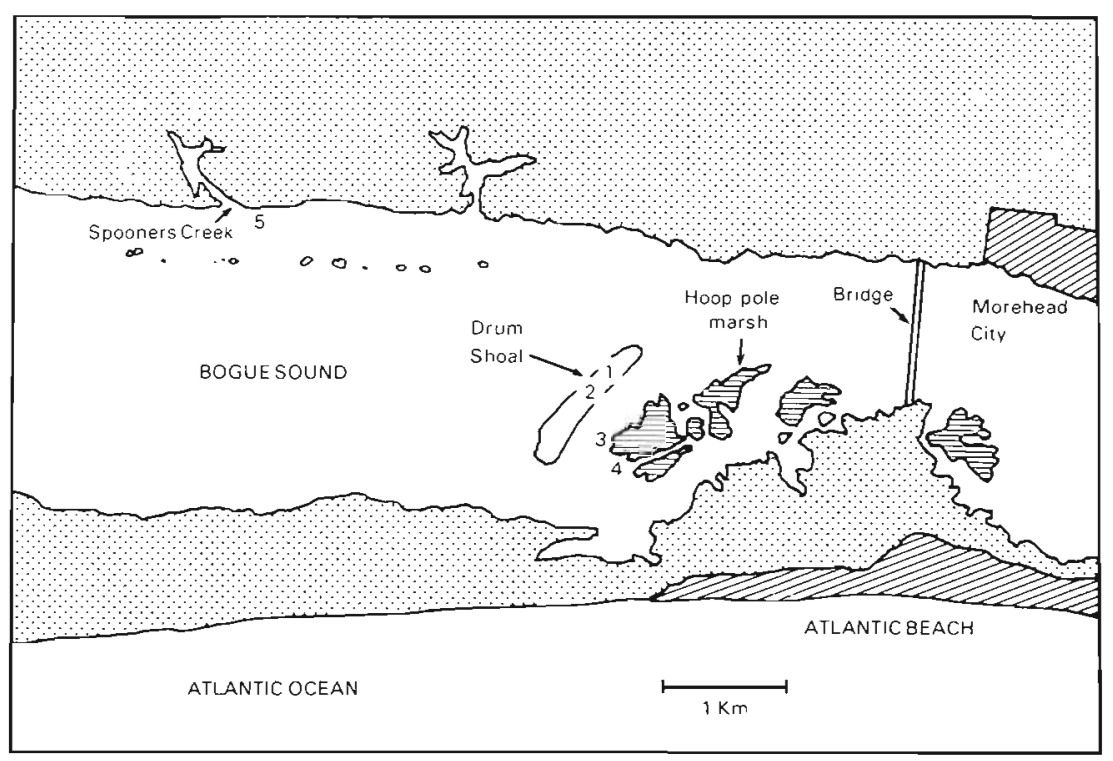

described by Kenworthy (1981). This is an indirect method based on measurements of the time interval between leaf scars (plastichromes) on the seagrass rhizome and the known weight of individual leaves of various ages measured from biomass samples.

Leaf production in dry wt $\mathrm{m}^{-2} \mathrm{~d}^{-1}$ was estimated by multiplying shoot production by density of shoots (no. $\mathrm{m}^{-2}$ ). Shoot density was determined from random samples of biomass collected in each eelgrass bed. Kenworthy (1981) provides further details concerning all aspects of this method of estimating production.

\section{RESULTS}

\section{Phillips Island}

The majority of surface-drifting plant material exported from the Phillips Island eelgrass bed consisted of complete or partially complete green Zostera marina blades with dead (brown) tips and epiphytes still attached. Complete shoots with rhizomes, roots, and blades were also collected but in much smaller amounts. Of the total amount of $Z$. marina collected during summer (the period of maximal export), approximately $65 \%$ was live, $33 \%$ was dead (brown), and $2 \%$ was rhizome. The macroalgal fraction primarily consisted of living fragments of Sargassum, Ectocarpus, and Aghardiella spp. The Spartina alterniflora fraction consisted almost entirely of dead portions of mature stems or rhizomes

Maximum Zostera marina export rates of 195 to 240 $\mathrm{kg}$ afdw $\mathrm{mo}^{-1}$ were followed by a rapid reduction in

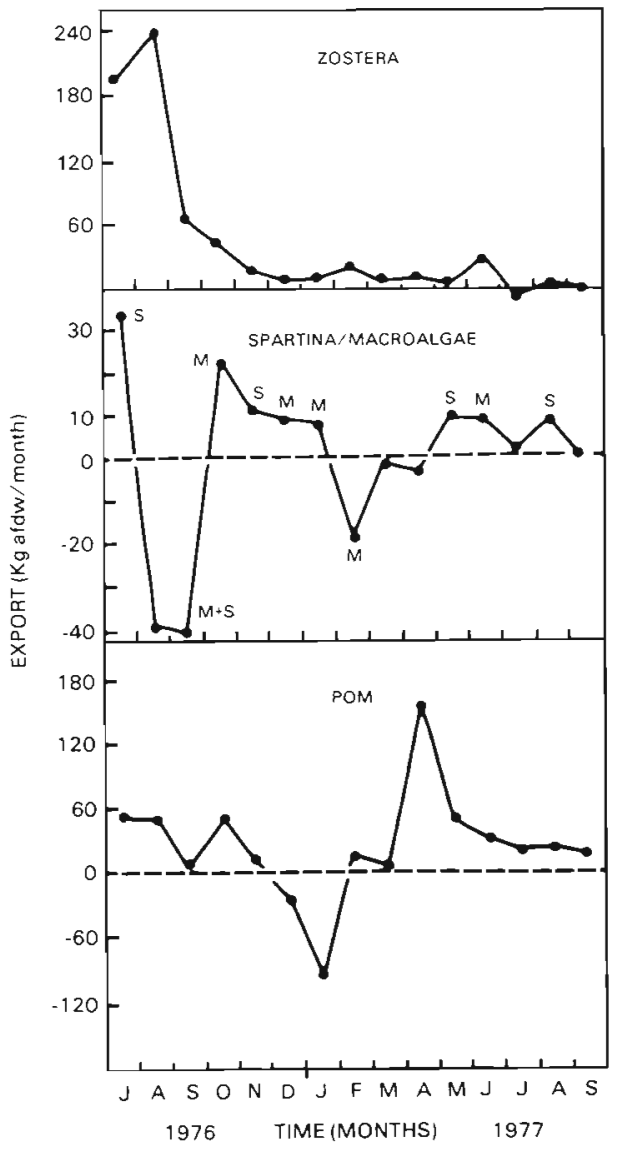

Fig. 5. Rates of export of surface drifting plant detritus (in $\mathrm{kg}$ afdw $\mathrm{mo}^{-1}$ ) estimated to occur at the Phillips Island eelgrass bed during 1976-1977. Each point represents mean $\mathrm{kg} \mathrm{mo}^{-1}$ exported based on observed daily rates ( $n=8$ to 20 for each point) 
export during September and October and low export rates from November 1976 to August 1977 (Fig. 5). The reduction in September was accompanied by a major drop in $Z$. marina biomass, which continued through August 1978 (based on visual observations of blade loss plus aerial photographs of the bed). Analysis of variance showed a significant net export (as g afdw tide $^{-1}$ ) on $64 \%$ of the days sampled between July 1976 and February 1977. Since $Z$. marina biomass had decreased greatly by February 1977, no significant net export occurred on $77 \%$ of the days sampled from March to September 1977 ( $p=0.05$ in all tests).

Since net export was calculated from the difference in mean amounts of material caught in the import and export nets, it was not possible to calculate a standard deviation for this estimate. However, standard deviations and co-efficients of variation were calculated for mean amounts of 'Total Zostera marina' (leaves, roots and rhizome sub-fractions), in order to provide an estimate of the variation in amounts of material caught between nets. The grand mean coefficient of variation for $54 \mathrm{~d}$ of data (13 Jul 1976 to 15 Feb 1977) for the import nets was $106 \pm 47 \%$. The grand mean coefficient of variation of material caught in the export nets was $56 \pm 31 \%$. A graph was also constructed which showed the cumulative mean coefficient of variation versus increasing number of samples collected. After about 20 data points, the amount of variation in the cumulative mean coefficient became greatly reduced. The same reduction in variation occurred after about 30 sampling points for the import nets. This analysis provides some idea of the amount of between-net variation involved.

The amount of Zostera marina exported during July and August 1976 ranged from 7.3 to $9.0 \%$ of the total aboveground biomass and production in the bed. The mean aboveground biomass in July and August was
$66.48 \pm 38.41 \mathrm{~g}$ afdw $\mathrm{m}^{-2}$ in the $40,000 \mathrm{~m}^{2}$ area covered by eelgrass, yielding a total biomass for the Phillips Island bed of $2.66 \times 10^{3} \mathrm{~kg}$ afdw. The percent exported in July, therefore, was $\left(195 \mathrm{~kg} / 2.66 \times 10^{3}\right) \times$ $100=7.3 \%$, and in August $(240 \mathrm{~kg})$ was $9.0 \%$. However, these values could possibly range from 1 to $20 \%$ based on the observed variations in export and biomass. Similarly, if $2.63 \mathrm{~g}$ afdw $\mathrm{m}^{-2} \mathrm{~d}^{-1}$ is the assumed production of $Z$. marina in July and August (Penhale 1977), total production per month would average $3156 \mathrm{~kg}$ afdw (i.e. $2.63 \mathrm{~g}_{\text {afdw m}} \mathrm{m}^{-2} \mathrm{~d}^{-1} \times$ $\left.40,000 \mathrm{~m}^{2} \times 30 \mathrm{~d}\right)$. This indicates that 6 to $8 \%$ of the production was exported per month during July and August 1976.

Movement of Zostera marina was affected significantly by wind, as observed on several days when wind caused surface-drifting plant material to be transported in the direction opposite tidal flow. For example, during the afternoon of 18 August 1976, a 50 to $60 \mathrm{~km} \mathrm{~h}^{-1}$ wind from the NE produced surface transport of $2.2 \mathrm{~kg}$ afdw of $Z$. marina in the opposite direction to the flooding tide. That morning the wind had been in the same direction as the tide and $3.9 \mathrm{~kg}$ of $Z$. marina were exported with the tide. Similar effects were observed on 7 other days with winds of approximately the same strength.

The seasonal pattern of export of macroalgae and Spartina alterniflora from the Phillips Island bed is summarized in Fig. 5. During August and September 1976, import of $S$. alterniflora and macroalgae (primarily Sargassum spp.) was observed, followed by net export of macroalgae (Gracilaria, Dictyota, Aghardiella spp.) and S. alterniflora from October to January, and import of the brown alga Ectocarpus spp. in February. The following spring and summer, net export of S. alterniflora and macroalgae was observed. Total material exported ranged from 4 to $36 \mathrm{~kg}$ afdw $\mathrm{mo}^{-1}$,

Table 1. Zostera marina. Comparison of biomass and production with export from Harkers Island and Middle Marsh beds in 1978 (negative sign indicates import)

\begin{tabular}{|c|c|c|c|c|c|}
\hline & $\begin{array}{c}\text { Biomass } \\
(\mathrm{kg})\end{array}$ & $\begin{array}{l}\text { Export } \\
\left(\mathrm{kg} \mathrm{mo}^{-1}\right)\end{array}$ & $\begin{array}{l}\text { Export as \% } \\
\text { of biomass }\end{array}$ & $\begin{array}{l}\text { Production } \cdots \\
\quad\left(\mathrm{kg} \mathrm{mo}^{-1}\right)\end{array}$ & $\begin{array}{l}\text { Monthly export as } \% \\
\text { of monthly production }\end{array}$ \\
\hline \multicolumn{6}{|c|}{ Harkers Island } \\
\hline Jun & 6774 & 2184 & 32 & & 30 \\
\hline Jul & 7736 & 934 & 12 & 7050 & 13 \\
\hline Aug & 2209 & 722 & 33 & & 10 \\
\hline \multicolumn{6}{|c|}{ Middle Marsh } \\
\hline Jun & 5746 & -9.9 & -0.2 & & - \\
\hline Jul & 5469 & 78 & 1.4 & 3180 & 2.5 \\
\hline Aug & 1188 & 30 & 2.5 & & 0.9 \\
\hline
\end{tabular}




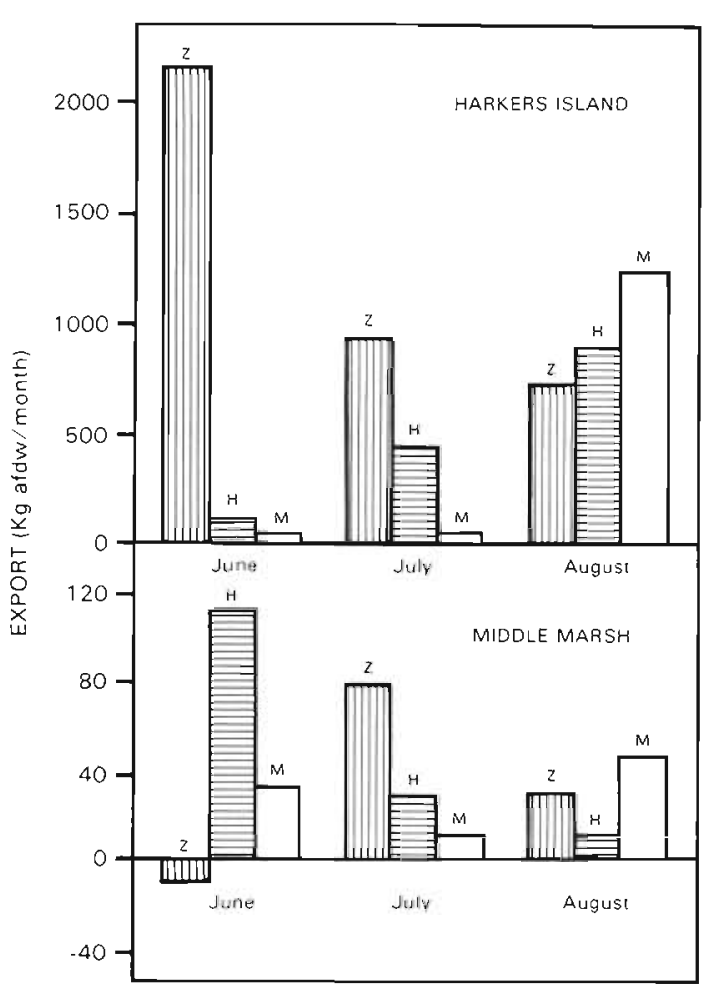

Fig. 6. Comparison of export at Harkers Island and Middle Marsh beds during summer 1978. Mean monthly values are based on daily rates for 6 to $10 \mathrm{~d}$ per bed for the summer. $Z=$ Zostera marina; $\mathrm{H}=$ Halodule wrightii; $\mathrm{M}=$ macroalgae/ Spartina alterniflora fraction

while that imported ranged from 1 to $41 \mathrm{~kg}$ afdw $\mathrm{mo}^{-1}$ (Fig. 5). Analysis of variance showed that export of these materials was statistically significant on $64 \%$ of all days sampled ( $\mathrm{p}=0.05$ in all tests). A StudentNewman-Keuls (SNK) test showed no statistical differences in magnitude of total material exported between months. The lack of differences was attributed to the large amount of variation in material caught between replicate nets.

Export of POM from Phillips Island ranged from 9 to $156 \mathrm{~kg}$ afdw $\mathrm{mo}^{-1}$ (Fig. 5). Import of approximately $95 \mathrm{~kg}$ afdw occurred in January 1977. There was significant net export of POM from the bed on $38 \%$ of the days sampled ( $\mathrm{p}=0.05)$. However, the SNK test showed no differences in export between the months that were sampled. Evaluation of plankton net material showed that the POM fraction consisted of approximately 10 to $30 \%$ zooplankton during summer but from 90 to $95 \%$ zooplankton in winter.

\section{Middle Marsh and Harkers Island}

The analysis of variance showed that except for 2 dates there was statistically significant net export of Zostera marina and Halodule wrightii from Middle Marsh and Harkers Island. Based on the 6 data sets collected at Harkers Island, net export of $Z$. marina (all fractions) averaged $2184 \mathrm{~kg}$ afdw for June, $934 \mathrm{~kg}$ for July, and $722 \mathrm{~kg}$ for August (Fig. 6; Table 1). Export of $H$. wrightii at Harkers Island followed an opposite pattern, increasing from $116 \mathrm{~kg}$ in June to $446 \mathrm{~kg}$ in July and $887 \mathrm{~kg}$ in August (Fig. 6). This increase was paralleled by a simultaneous increase in $H$. wrightii biomass (Tables $2 \& 3$ ). Export of macroalgae from Harkers Island was not significant in June and July, but $1200 \mathrm{~kg}$ afdw (primarily as Ectocarpus) were exported in July (Fig. 6). Large amounts of Ectocarpus spp. were observed within this bed during August.

A slight net import of Zostera marina at Middle Marsh occurred in June. Approximately $78 \mathrm{~kg}$ afdw was exported in July and $27 \mathrm{~kg}$ in August (Fig. 6). The pattern shown by Halodule wrightii at Middle Marsh was opposite that at Harkers Island, with $896 \mathrm{~kg}$

Table 2. Halodule wrightii. Comparison of biomass and production with export from Harkers Island and Middle Marsh beds in 1978

\begin{tabular}{|c|c|c|c|c|c|}
\hline & $\begin{array}{l}\text { Biomass }^{*} \\
(\mathrm{~kg})\end{array}$ & $\begin{array}{c}\text { Export } \\
\left(\mathrm{kg} \mathrm{mo} \mathrm{mo}^{-1}\right)\end{array}$ & $\begin{array}{l}\text { Export as \% } \\
\text { of biomass }\end{array}$ & $\begin{array}{l}\text { Production } \cdots \\
\quad\left(\mathrm{kg} \mathrm{mo} \mathrm{mo}^{-1}\right)\end{array}$ & $\begin{array}{l}\text { Monthly export as \% } \\
\text { of monthly production }\end{array}$ \\
\hline \multicolumn{6}{|c|}{ Harkers Island } \\
\hline Jun & 313 & 116 & 37 & & 2.8 \\
\hline Jul & 605 & 446 & 74 & 4189 & 10.6 \\
\hline Aug & 1196 & 887 & 74 & & 21.2 \\
\hline \multicolumn{6}{|c|}{ Middle Marsh } \\
\hline Jun & 659 & 112 & 17 & & 3.6 \\
\hline Jul & 1155 & 27 & 2 & 3091 & 0.9 \\
\hline Aug & 713 & 13 & 2 & & 0.4 \\
\hline \multicolumn{6}{|c|}{$\begin{array}{l}\text { - Of entire bed (afdw) } \\
\therefore \text { Mean rate of leaf production of whole bed for June, July and August (afdw) }\end{array}$} \\
\hline
\end{tabular}


Table 3. Biomass of Zostera marina live (ZL) and dead (ZD) fractions and Halodule wrightii (H) at Middle Marsh and Harkers Island during June, July and August, 1978. Values represent aboveground blade biomass in $\mathrm{g}$ afdw $\mathrm{m}^{-2}$

\begin{tabular}{|c|c|c|c|c|c|c|c|}
\hline \multirow[t]{2}{*}{ Date } & \multirow[t]{2}{*}{ Fraction } & \multicolumn{2}{|c|}{$\begin{array}{c}\text { Biomass at } \\
\text { Middle Marsh Deep }\end{array}$} & \multicolumn{2}{|c|}{$\begin{array}{l}\text { Biomass at } \\
\text { Middle Marsh Lagoon }\end{array}$} & \multicolumn{2}{|c|}{$\begin{array}{c}\text { Biomass at } \\
\text { Harkers Island }\end{array}$} \\
\hline & & Mean & SE & Mean & $\mathrm{SE}$ & Mean & $\mathrm{SE}$ \\
\hline 19 Jun 1978 & $\begin{array}{l}\mathrm{ZL} \\
\mathrm{ZD} \\
\mathrm{H}\end{array}$ & $\begin{array}{l}16.61 \\
12.07 \\
17.58\end{array}$ & $\begin{array}{r}14.23 \\
9.88 \\
15.92\end{array}$ & $\begin{array}{c}80.07 \\
42.27 \\
0.0\end{array}$ & $\begin{array}{l}45.69 \\
29.05\end{array}$ & $\begin{array}{r}43.61 \\
22.57 \\
3.06\end{array}$ & $\begin{array}{r}44.09 \\
20.40 \\
6.54\end{array}$ \\
\hline $19 \mathrm{Jul} 1978$ & $\begin{array}{l}\mathrm{ZL} \\
\mathrm{ZD} \\
\mathrm{H}\end{array}$ & $\begin{array}{l}15.48 \\
11.26 \\
30.43\end{array}$ & $\begin{array}{l}13.58 \\
10.95 \\
21.59\end{array}$ & $\begin{array}{r}68.79 \\
48.64 \\
0.38\end{array}$ & $\begin{array}{r}46.60 \\
39.68 \\
2.79\end{array}$ & $\begin{array}{r}52.21 \\
23.36 \\
5.91\end{array}$ & $\begin{array}{l}39.09 \\
26.63 \\
10.86\end{array}$ \\
\hline 31 Aug 1978 & $\begin{array}{l}\mathrm{ZL} \\
\mathrm{ZD} \\
\mathrm{H}\end{array}$ & $\begin{array}{r}0.98 \\
1.04 \\
19.01\end{array}$ & $\begin{array}{r}1.55 \\
2.37 \\
22.17\end{array}$ & $\begin{array}{c}16.95 \\
12.29 \\
0.0\end{array}$ & $\begin{array}{l}17.09 \\
14.40\end{array}$ & $\begin{array}{l}11.17 \\
10.40 \\
11.68\end{array}$ & $\begin{array}{l}12.91 \\
10.20 \\
11.69\end{array}$ \\
\hline
\end{tabular}

Table 4. Export of bottom drifting macrodetritus for June, July and August 1978

\begin{tabular}{|lc|}
\hline Fraction & Mean export $\left(\mathrm{kg} \mathrm{afdw} \mathrm{mo}^{-1}\right)$ \\
\hline Middle Marsh & \\
Total Zostera marina & 3.1 \\
Halodule wrightii & 0.3 \\
Macroalgae & -1189.0 \\
Spartina alterniflora & 0.5 \\
Harkers Island & \\
Total Zostera marina & 4.5 \\
Halodule wrightii & 194.0 \\
Macroalgae & 1574.0 \\
Spartina alterniflora & 0 \\
Ectocarpus spp. (August) & \\
\hline
\end{tabular}

Table 5. Biomass of Zostera marina and Halodule wrightii in Bogue Sound, August 1977

\begin{tabular}{|lcc|}
\hline Transect & Biomass $\left(\mathrm{g} \mathrm{afdw} \mathrm{m}^{-2} \pm 1 \mathrm{SD}\right)$ Sample size \\
\hline Zostera marina & & \\
1 & $2.40 \pm 3.13$ & 17 \\
2 & $12.80 \pm 12.54$ & 14 \\
3 & $16.89 \pm 10.11$ & 17 \\
4 & $1.95 \pm 4.03$ & 12 \\
5 & $14.66 \pm 19.91$ & 21 \\
Grand mean $=$ & 9.74 & \\
Halodule wrightii & & 17 \\
1 & $88.41 \pm 72.82$ & 17 \\
2 & $63.73 \pm 55.80$ & 12 \\
3 & $42.87 \pm 49.37$ & 21 \\
4 & $43.00 \pm 49.50$ & \\
5 & $17.80 \pm 23.53$ & \\
Grand mean $=$ & 51.15 & \\
\end{tabular}

exported in June, $27 \mathrm{~kg}$ in July and $13 \mathrm{~kg}$ in August. From 10 to $50 \mathrm{~kg}$ Spartina alterniflora and macroalgae were exported each month from the Middle Marsh bed.

Between 10 and $30 \%$ of the Zostera marina leaf biomass and production were exported monthly from the Harkers Island bed, while only 0.9 to $2.5 \%$ were exported from the Middle Marsh bed (Tables $1 \& 2$ ). Approximately 37 to $74 \%$ of the Halodule wrightii biomass was exported from the Harkers Island bed each month, and 2 to $17 \%$ from Middle Marsh (Table 2). Based on rates of production given for this area by Dillon (1971), from 3 to $21 \%$ of the $H$. wrightii production was exported each month at Harkers Island, and 0.4 to $3.6 \%$ at Middle Marsh.

Export of bottom-drifting Zostera marina was not substantial at Middle Marsh (Table 4). However, $39.8 \mathrm{~kg}$ afdw of macroalgae (Dictyota and Gracilaria spp.) were imported in June. At Harkers Island, export of bottom-drifting $Z$. marina was also negligible, but $194 \mathrm{~kg}$ of Halodule wrightii and $1574 \mathrm{~kg}$ of Ectocarpus were exported in this manner

\section{Bogue Sound}

Biomass of Zostera marina along 5 transects in Bogue Sound in August 1977 (Hoop Pole marsh bed) ranged from $1.95 \pm 4.03$ to $16.89 \pm 10.11 \mathrm{~g} \mathrm{afdw}^{-2}$. The grand mean ( $\mathrm{n}=81$ ) biomass for all 5 transects was $9.74 \mathrm{~g}_{\text {afdw }} \mathrm{m}^{-2}$ (Table 5). Biomass of Halodule wrightii along the same 5 transects ranged from $17.80 \pm 23.53$ to $88.41 \pm 72.82 \mathrm{~g} \mathrm{afdw}^{-2}$ (Table 5).

Mean rates of net export from Bogue Sound (average of net export for all days sampled during July and August 1977) ranged from $11.2 \mathrm{~kg} \mathrm{mo}^{-1}$ (for POM) to $150.2 \mathrm{~kg} \mathrm{mo}^{-1}$ (for Halodule wrightil). About $47.4 \mathrm{~kg}$ mo ${ }^{-1}$ of Zostera marina, $31.5 \mathrm{~kg} \mathrm{mo}^{-1}$ of macroalgae and $24.5 \mathrm{~kg} \mathrm{mo}{ }^{-1}$ of Spartina alterniflora were esti- 
mated to be exported from Bogue Sound during this same period (Table 6).

On days when the wind blew from the south at sufficient strength, export of drifting seagrass detritus was greatly reduced or even negative (i.e. imported) in Bogue Sound (Table 7). Export of seagrass material from Bogue Sound was much higher on calm days when wind speed was 0 to 5 knots. Export of fractions of other types of detritus was more variable (Table 7).

\section{DISCUSSION}

The results of this study illustrate a variety of important aspects regarding the export of plant detritus from eelgrass beds in the North River estuary. These are discussed according to the individual sites at which measurements were made.

\section{Phillips Island}

Export rates from Phillips Island varied seasonally and between years. The highest rate of export $(240 \mathrm{~kg}$ afdw mo $^{-1}$ ) occurred in August 1976. Export rates then dropped sharply through the remainder of 1976 and 1977 (Fig. 5). The maximum rate of export in the summer of 1976 is probably part of the typical seasonal pattern of Zostera marina in this estuary because this is the period of greatest temperature-related leaf stress. During low tide, leaves are exposed directly to the sun or are affected by high water temperatures in shallow tidal pools. A portion of the leaves are stressed under these conditions and eventually dehisce. These leaves are removed from the eelgrass bed on subsequent tidal cycles.

The peak biomass of Zostera marina in North Carolina typically occurs between March and June (Thayer et al. 1984), but the period of greatest temperature stress is usually in late summer. Therefore, maximum export rates and peak biomass do not necessarily occur at the same time in this system. Export of $Z$. marina leaves should be related in some degree to the rate of leaf turnover (productivity) since under conditions of higher turnover, more leaves are available for removal from the bed. However, this relation was not measured in the present study.

The results at Phillips Island may also reflect a longer term pattern of reduction in biomass caused by

Table 6. Export of surface drifting detritus from Bogue Sound during July and August 1977

\begin{tabular}{|c|c|c|c|c|c|c|}
\hline Fraction & $\begin{array}{l}\text { Mean' ebb } \\
\left.\text { (g tide }{ }^{-1}\right)\end{array}$ & $\begin{array}{l}\text { Mean' flood } \\
\qquad\left(g \text { tide }^{-1}\right)\end{array}$ & (g tide $\left.{ }^{-1}\right)$ & $\begin{array}{l}\text { Mean net export } \\
\qquad\left(\mathrm{kg} \text { tide }^{-1} \cdots\right)\end{array}$ & $\left(\mathrm{kg} \mathrm{mo}^{-1}\right)$ & $\begin{array}{l}\% \text { of total } \\
\text { biomass } \cdots\end{array}$ \\
\hline Live Zostera marina & 1137.7 & 694.8 & 442.9 & 0.89 & 26.7 & \\
\hline Dead Zostera marina & 397.3 & 105.9 & 291.4 & 0.58 & 17.4 & \\
\hline Zostera marina rhizomes & 72.7 & 16.6 & 56.1 & 0.11 & 3.4 & \\
\hline Total Zostera marina & 1607.7 & 817.3 & 790.4 & 1.58 & 47.4 & .01 \\
\hline Spartina alterniflora & 1235.3 & 827.8 & 407.5 & 0.82 & 24.5 & \\
\hline Halodule wrightii & 4114.4 & 1611.7 & 2502.7 & 5.01 & 150.2 & .08 \\
\hline Macroalgae & 885.6 & 360.5 & 525.1 & 1.05 & 31.5 & \\
\hline Particulate ${ }^{*}$ organic matter & 2038.7 & 1852.5 & 186.2 & 0.37 & 11.2 & \\
\hline \multicolumn{7}{|c|}{$\begin{array}{l}\text { Mean afdw values for all days sampled } \\
\ldots \quad 2 \text { ebb tides, } 2 \text { flood tides } \\
\text {... \% of total biomass in eastern Boque Sound estimated to occupy the bottom area covered by the } 67 \mathrm{~km}^{2} \text { tidal pris }\end{array}$} \\
\hline
\end{tabular}

Table 7. Comparison of export from Bogue Sound on windy and calm days

\begin{tabular}{|c|c|c|c|c|c|c|}
\hline \multirow[b]{2}{*}{ Date } & \multirow[b]{2}{*}{$\begin{array}{l}\text { Wind } \\
\text { (knots) }\end{array}$} & \multicolumn{5}{|c|}{ Net export ( $g$ afdw tide ${ }^{-1}$ ) (mean caught in ebb - flood) } \\
\hline & & $\begin{array}{l}\text { Zostera } \\
\text { marina }\end{array}$ & $\begin{array}{c}\text { Halodule } \\
\text { wrightii }\end{array}$ & $\begin{array}{l}\text { Spartina } \\
\text { alterniflora }\end{array}$ & Macroalgae & POM \\
\hline 2 Aug 1977 & $5-15^{\cdots}$ & -326.4 & -681.4 & +1146.6 & +212.5 & -25.0 \\
\hline 10 Aug 1977 & $15-20^{\cdots}$ & +154.0 & -819.8 & -436.3 & -86.7 & -396.7 \\
\hline 18 Aug 1977 & $0-5$ & $+1910.4^{\circ}$ & $+3568.8^{\circ}$ & +1558.7 & +1396.7 & +1094.5 \\
\hline 25 Aug 1977 & $0-5$ & +562.2 & $+7665.9^{\circ}$ & -69.4 & +926.2 & -323.6 \\
\hline \multicolumn{7}{|c|}{$\begin{array}{l}\text { Significant difference at } P=0.01 \text { level between mean ebb and mean flood values } \\
\text { - Wind from south }\end{array}$} \\
\hline
\end{tabular}


elevation of the eelgrass bed. Elevation is a result of trapping of sediments by the system of leaves and rhizomes. As the bed builds vertically, plants are exposed increasingly to intertidal conditions (Thayer et al. 1984). This eventually causes dieback, biomass reduction, and therefore, reduced export of blade material. Unusually large reductions in the biomass of Zostera marina in late summer at Phillips Island were observed in 2 previous studies (Thayer et al. 1975b, Penhale 1977), which is evidence for a long-term cycle of bed build-up. Such a long-term cycle may have a major effect on export rates in this eelgrass bed.

During winter, significant amounts of export may also occur from the Phillips Island bed, although the data from this study do not support this. Biomass of Zostera marina at Phillips Island had been much higher in previous years (Penhale 1977), and during winter in those years, average production rates were never below $50 \%$ of summer rates (Penhale 1977). Rates of export in winter would be expected to be correlated with the amount of leaves present and the rate of turnover of leaf material. It is therefore likely that significant export occurred in winter during those years when biomass was higher. This is another example of the possible effects of the long-term successional cycle of bed elevation mentioned previously.

During July and August 1976, 195 to $240 \mathrm{~kg}$ afdw $\mathrm{mo}^{-1}$ of Zostera marina detritus (exclusive of POM) was exported from the Phillips Island bed. Dividing export values by bed area $\left(40,000 \mathrm{~m}^{2}\right)$ provides an estimate of 4.9 to $6.0 \mathrm{~g}$ afdw $\mathrm{mo}^{-2}$ exported. Assuming that export rates for this bed were comparable with other beds in the area at that time and that eelgrass covered $17 \%$ of the $532 \mathrm{~km}^{2}$ study area (Williams 1973), the amount of $Z$. marina exported to the estuary would have approximated 456 to 558 metric tons $\mathrm{mo}^{-1}$ during summer.

Thayer et al. (1975b) estimated that about $45 \%$ of the Zostera marina produced in the Phillips' Island bed (3165 kg afdw mo ${ }^{-1}$ during summer) was available for export. If this amount had indeed been exported, it would have equalled approximately $1420 \mathrm{~kg} \mathrm{mo}^{-1}$. However, only 6 to $8 \%$ was in fact exported, indicating that the difference, i.e. 1180 to $1225 \mathrm{~kg}$, was available for incorporation into sediments, was cycled within the meadow by bacteria and detritivores, or was available for export as POM or dissolved organic material (DOM).

Because of variability it was not possible to show statistical differences in rates of POM export from Phillips Island between seasons. However, POM quantities could exceed those contributed by surface-floating blade material (Table 6). The large variability of POM export was probably produced by a variety of factors, including seasonal differences in biological production (i.e. of Zostera marina, phytoplankton, and zooplankton), as well as seasonal and spatial variation in winds and currents.

Approximately $65 \%$ of the Zostera marina exported in summer from Phillips Island consisted of green (live) blades. Because $Z$. marina decomposes relatively slowly (Harrison \& Mann 1975, Thayer et al. 1984), the green leaf material would not be suitable as a food source for detritivores. The blades decompose slowly and reach their optimal nutritional state as detritus only after several months (Thayer et al. 1977). The rate of decay is a function of degree of tidal inundation, temperature, and other local site conditions (Josselyn 1978. Thayer et al. 1984). An immediate role of exported $Z$. marina may therefore not be as a food source but rather as habitat for benthic animals in unvegetated areas. Local fishermen have reported collecting large amounts of $Z$. marina in the deeper portions of Newport River estuary during late summer and early fall, indicating these may be primary sites of accumulation for exported material. Since $Z$. marina is highly epiphytized in late summer (Penhale \& Smith 1977), exported plant material may also provide an immediate food source (in the form of its epiphytes) for benthic animals in these same areas.

Since exported Zostera marina is not available for several months as a detrital food source, other more readily decomposable plants may serve this function. Macroalgae are composed of more labile components and have more rapid decay rates than $Z$. marina (Tenore 1977, Josselyn 1978). These may serve a more immediate role as detrital food sources. Surface export of macroalgae was highly variable at all locations sampled in the present study. Most of this drifting material appears to leave and enter the seagrass bed along the bottom. Macroalgal export may occur in substantial quantities in this estuary.

\section{Middle Marsh and Harkers Island}

The studies at Middle Marsh and Harkers Island illustrate how bed enclosure, intertidal conditions, winds and current interaction, and seasonal changes in plant biomass all affect rates of export in this estuary. Effects of enclosure by salt marshes are indicated by the order of magnitude difference in relative export rates between Harkers Island and Middle Marsh. This difference was probably caused by greater physical retention of detritus in the Middle Marsh bed. Internal processing and recycling of Zostera marina blades and other detritus is probably much greater in an enclosed bed such as Middle Marsh. The enclosure of Middle Marsh also reduced the amount of wind scouring of the bottom, thereby reducing detrital suspension. Both 
wind and hydrologic conditions thus reduced the total amount of export from this bed.

Temperature measurements over midday during a spring low tide in August 1978 demonstrate an additional effect of bed enclosure. Rapid mid-afternoon rises in water temperature (maximum temperatures of up to $34^{\circ} \mathrm{C}$ ) were recorded at Middle Marsh, due to reduced current speed and shallow depth, but only a small rise in temperature $\left(+2 \mathrm{C}^{\circ}\right.$; up to $30^{\circ} \mathrm{C}$ maximum) was noted at Harkers Island because of the faster flow of water. Repeated temperature stress, combined with very low tides and reduced circulation, would be expected to produce leaf mortality and blade loss of Zostera marina. This hypothesis is supported by the reduction of $Z$. marina biomass which occurred at Middle Marsh in August 1978 (Table 1). It does not however explain a similar decrease in biomass observed at Harkers Island in August since this bed is located in open water with good circulation. It is possible that blade loss at Harkers Island was related to unusually high late summer temperatures since $Z$. marina is at the extreme southern edge of its range in Beaufort. This could also explain the increase in biomass of Halodule wrightii at Harkers Island since this tropical species is at the northern edge of its range in Beaufort and would increase under warmer conditions. An alternative hypothesis could be that over the period of several years the Harkers Island bed has become increasingly elevated due to trapping of sediments by leaves and rhizomes, as may have occurred at Phillips Island. This would expose $\mathcal{Z}$. marina to intertidal stress, ultimately producing higher rates of blade loss. Some Z. marina beds at Harkers Island were observed to be exposed to such intertidal conditions.

The interaction between wind and tidal currents also has an important effect on export in this estuary. The amount of export was greatest when wind and tide were working in the same direction. Less export resulted when wind and tide worked in opposition. In the present study, wind velocities of over $50 \mathrm{~km} \mathrm{~h}^{-1}$ were capable of causing transport as high as $0.3 \mathrm{~m} \mathrm{~s}^{-1}$ against the tidal current. Lower wind velocities would also have some effect but this was not examined further in the present study.

\section{Bogue Sound}

The effect of the estuary's shape and physical orientation on export is illustrated by the results of the Bogue Sound study. Bogue Sound is long and narrow and prevailing winds blow across its east-west axis. Larger amounts of surface drifting material wash up on beaches or are carried into deeper channels as wind velocity increases. A significant amount of detritus from eelgrass beds may also be deposited in Spartina alterniflora marshes, and could constitute a detrital input to this system. Other researchers have also reported substantial input of Zostera marina detritus to salt marshes (Gallagher et al. 1984). The total amount of seagrass exported from Bogue Sound to adjacent areas, however, was small relative to the total amount of available biomass.

To examine the relative amounts of Zostera marina exported from Bogue Sound, rates of export were compared with the total amount of biomass of this seagrass in the Sound. Dillon (1971) estimated that the average biomass of $Z$. marina was $273 \mathrm{~g} \mathrm{~m}^{-2}$ in 1966 (based on data from 4 transects) and that this seagrass covered approximately $55 \%$ of the total of the Sound. Since the eastern end of Bogue Sound (the end from which export was measured) is affected by a tidal prism of about $67 \mathrm{~km}^{2}$ in horizontal extent it is reasonable to assume that most of the $Z$. marina exported originated primarily from this area. The total biomass of $Z$. marina within the $67 \mathrm{~km}^{2}$ tidal prism would therefore roughly equal $0.273 \mathrm{~kg} \mathrm{~m} \mathrm{~m}^{-2} \times 67 \mathrm{~km}^{2} \times 10^{6} \mathrm{~m}^{2} \mathrm{~km}^{-2} \times 0.55$ $=1.01 \times 10^{7} \mathrm{~kg}$. Using the results of the summer 1977 sampling, the average biomass of $Z$. marina in the Eastern part of the Sound was determined to be $9.74 \mathrm{~g}$ afdw $\mathrm{m}^{-2}$ (Table 5). Using this as an average for the whole sound, and assuming $Z$. marina still covered $55 \%$ of the bottom, the total biomass would be $0.00974 \mathrm{~kg} \mathrm{~m} \mathrm{~m}^{-2} \times 67 \mathrm{~km}^{2} \times 10^{6} \mathrm{~m}^{2} \mathrm{~km}^{-2} \times 0.55=$ $3.6 \times 10^{5} \mathrm{~kg}$. Using either of the above means of estimating biomass, it can be concluded that the amounts of $Z$. marina exported on a monthly basis $\left(47.4 \mathrm{~kg} \mathrm{mo} \mathrm{mo}^{-1}\right)$ during summer were an extremely small percentage of the estimated total biomass present within the Sound. This results from retention of the material within the Sound caused by its east-west orientation and the action of wind. Evidence for retention was the commonly observed build-up of seagrass detritus (leaves) on the beaches of the northern side of the Sound. It is not possible to estimate the relative amounts of macroalgae and Halodule wrightii exported and/or retained since no recent biomass data are available for the entire Sound. However, amounts exported relative to total biomass are probably also small due to the above factors.

Estimates of the total amount of detrital export for all Zostera marina beds in the estuary can be made based on data from Harkers Island and Middle Marsh. This exported material may be transported to other parts of the estuary via tidal channels, where it may accumulate (some detrital material may also be transported to nearshore oceanic waters, but the amounts involved are not yet known). Dividing the mean amounts of Z. marina (in $\mathrm{kg}$ afdw $\mathrm{mo}^{-1}$ ) by the areas of each bed yields values of 1.2 and $12.9 \mathrm{~g}$ afdw $\mathrm{mo}^{-1} \mathrm{~m}^{-2}$ for these 
2 sites, respectively. Multiplying the values for Harkers Island and Middle Marsh by the total area of the estuary occupied by $Z$. marina $\left(93 \mathrm{~km}^{2}\right)$ yields a range of 112 to 1200 metric tons of $Z$. marina exported each month during summer. These values can be compared with the summer Phillips Island estimates, which when extrapolated to the whole estuary yielded a range of 455 to $558 \mathrm{t} \mathrm{mo}^{-1}$ (4.9 to $6.9 \mathrm{~g}$ afdw $\mathrm{mo}^{-2}$ ). This is within the same order of magnitude as the estimates made for the Harkers Island and Middle Marsh beds.

Similar estimates for Halodule wrightii are more difficult to make because few data on biomass are available. Dillon (1971) reported that $H$. wrightii is capable of rapid horizontal growth. Within $1 \mathrm{yr}$, it increased from a rare species to cover about $4 \%$ of the bottom of Bogue Sound. Based on measurements by the present author's of $H$. wrightii biomass in Bogue Sound and results of aerial surveys conducted between 1975 and 1978, it can be concluded that $H$. wrightii abundance had increased greatly by 1978 . Extensive seagrass beds covering several $\mathrm{km}^{2}$ were noted in the summer of 1978 just inside of Core Banks, immediately north of Cape Lookout (Fig. 1) and in other similar areas. Observations made at Core Banks confirmed that these beds were predominantly $H$. wrightii. If $H$. wrightii were to occupy an area equivalent to that of eelgrass in this estuary $\left(93 \mathrm{~km}^{2}\right)$, between 90 and $475 \mathrm{t}$ $\mathrm{mo}^{-1}$ ( 1.0 to $5.1 \mathrm{~g}$ afdw mo ${ }^{-1} \mathrm{~m}^{-2}$ ) could be contributed to the detrital pool during summer.

\section{CONCLUSIONS}

The estimates of export made in this paper are affected by several factors, which must be considered in making conclusions concerning the amount of detri- tal material involved. These factors include: (1) variation in tidal volume discharge estimates; (2) contagious (clumped) distribution of drifting plant material; and (3) long-term change in seagrass abundance and distribution.

Tidal volume discharge varies due to lunar effects and effect of wind. Export estimates were corrected for such variation in the present study. Lunar effects on tidal amplitude were corrected for by use of tide table information when calculating volume exchange on each day of the month. Wind effects were estimated by comparing amounts of material caught in fixed nets to that collected in freely swinging nets. Clumping of drifting plant material resulted in large variability in the amount of plant material collected between different nets. This is related in part to current and wind patterns which produced windrows of drifting material. Use of more and/or larger nets would help to reduce this type of variation in data in future studies.

Estimates of export made in the present study were compared to those reported recently in the Virgin Islands (Table 8 ). Rates for open beds in the 2 studies were similar, with values ranging from 0.23 to $0.56 \mathrm{~g}$ afdw $\mathrm{m}^{-2} \mathrm{~d}^{-1}$ for Zostera marina and Halodule wrightii, respectively at Harkers Island, and from 0.13 to

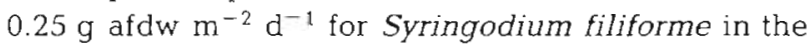
Virgin Islands (Zieman et al. 1979, Thayer et al. 1984). Leaf removal by grazing parrotfish was hypothesized to be a major factor in producing export of $S$. filiforme in the Virgin Islands. In Beaufort, the major factor affecting export is probably temperature-related stress during low tide and the interaction of winds and currents. At present, we cannot explain why the rates of blade export from these seagrass beds in the Virgin Islands and Beaufort were so similar. Nevertheless, large amounts of plant material were exported.

Table 8 . Comparison of export of seagrass detritus by different species from different geographical areas

\begin{tabular}{|c|c|c|c|c|c|}
\hline Species & Location & $\begin{array}{c}\text { Export } \\
\left(g \text { afd } \mathrm{m}^{-2} \mathrm{~d}^{-1}\right)\end{array}$ & $\begin{array}{l}\% \text { of total monthly } \\
\text { production exported }\end{array}$ & $\%$ of biomass & Source \\
\hline Zostera marina & Phillips Island & $0.01-0.26^{\mathrm{a}}$ & $6-8^{6}$ & $1-20$ & This study \\
\hline Zostera marina & Middle Marsh & $0.05^{\mathrm{b}}$ & $0.9-2.5^{b}$ & $0.9-2.5^{b}$ & This study \\
\hline Zostera marina & Harkers Island & $0.23-0.57^{b}$ & $10-30^{\mathrm{b}}$ & $10-30^{b}$ & This study \\
\hline Halodule wrightii & Middle Marsh & $0.04^{\mathrm{b}}$ & - & $2-17$ & This study \\
\hline Halodule wrightif & Harkers Island & $0.23^{\mathrm{b}}$ & - & $40-75$ & This study \\
\hline Syringodium & Tague Bay, & & & & \\
\hline filiforme & Virgin Islands & $0.13-.25^{c}$ & $60-100$ & - & Zieman et al. (1979) \\
\hline Thalassia & Tague Bay, & & & & \\
\hline testudinum & Virgin Islands & $0.0^{\mathrm{d}}$ & 1 & - & Zieman et al. (1979) \\
\hline \multicolumn{6}{|c|}{ a Annual range } \\
\hline \multicolumn{6}{|c|}{ Maximum summer value } \\
\hline \multicolumn{6}{|c|}{ Values given in afdw based on assumed $70 \%$ organic content of $S$. filiforme (Zieman et al. 1982) } \\
\hline
\end{tabular}


Export rates estimated in the present study can be compared to amounts of detritus entering the system from Spartina alterniflora, another major primary producer in this system. Williams (1973) estimated that the annual production of $S$. alterniflora in the study area amounted to $7.72 \times 10^{6} \mathrm{~kg} \mathrm{C} \mathrm{yr}^{-1}\left(7720 \mathrm{t} \mathrm{C} \mathrm{yr}^{-1}\right)$. Hopkinson \& Hoffman (1984) estimated that from 10 to $50 \%$ of the total amount of $S$. alterniflora produced in a Georgia estuary was exported. Assuming that this percentage is roughly the same for North Carolina marshes, the total amount of $S$. alterniflora exported from the North River estuary would range from 772 to $3860 \mathrm{t} \mathrm{C} \mathrm{yr}^{-1}$. Because this estimate includes DOC, it is not directly comparable to the 148 to $1573 \mathrm{t} \mathrm{c} \mathrm{yr}^{-1}$ of detritus estimated to be exported by Zostera marina in

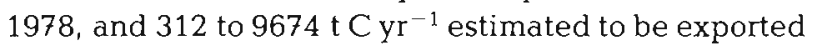
for 1976 and 1977 from Phillips Island. These estimates are based on a $38 \%$ carbon content of live $Z$. marina (Thayer et al. 1977). An additional $600 \mathrm{t} \mathrm{C} \mathrm{yi}^{-1}$ has been estimated to be added as DOC as the result of excretion by eelgrass and its epiphytes (Penhale \& Smith 1977). Export of $Z$. manina therefore equalled or exceeded that by $S$. alterniflora in this system.

Export of plant detritus from eelgrass beds in all likelihood plays a major role in the carbon cycle of the estuary near Beaufort. The large quantities and variety of types of materials produced indicate that export may contribute to a series of detrital pools of varying nutritional values. This may help promote secondary productivity throughout the year by maintaining a more constant food supply for detritivores. Although rates of export from seagrass beds vary greatly, the detritus itself probably plays an important ecological role in unvegetated portions of this estuary.

Acknowledgements. This material is based on research supported by the National Science Foundation under Grant No. OC77-07101. The senior author would also like to gratefully acknowledge the assistance given by $\mathrm{Dr} \mathrm{T}$. R. Rice, Director of Southeast Fisheries Center's Beaufort Laboratory, for his generous cooperation in the completion of the project and for providing facilities. Sincere thanks are also extended to P. L. Bach for typing the draft manuscript, and to J. Kenworthy, M. Fonseca, and M. Robertson for their important contribution of ideas concerning the project.

\section{LITERATURE CITED}

Blegvad, H. (1914). Food and condition of nourishment among the communities of invertebrate animals found on or in the sea bottom in Danish waters. Rep. Dan. Biol. Stn 22: 41-78

Dillon, C. R. (1971). A comparative study of the primary productivity of estuarine phytoplankton and macrobenthic plants. Ph. D. thesis, Univ. North Carolina, Chapel Hill

Gallagher, J. L., Kibby, H. V., Skirvin, K. W. (1984). Detritus processing and mineral cycling in seagrass (Zostera) litter in an Oregon salt marsh. Aquat. Bot. 20: 97-108

Harrison, P. G., Mann, K. H. (1975). Detritus formation from eelgrass (Zostera marina) L.: the relative effects of fragmentation and decay, Limnol. Oceanogr. 20: 924-934

Hopkinson, C. S., Hoffman, F. A. (1984). The estuary extended - a recipient system study of estuarine outwelling in Georgia. In: Kennedy, V. S. (ed.) The estuary as a filter Academic Press, New York, p. 313-330

Josselyn, M. N. (1978). The contribution of marine macrophytes to the detrital pool of the Great Bay estuary system, N. H. Ph. D. thesis, Univ. New Hampshire, Durham

Josselyn, M. N., Mathieson, A. C. (1980). Seasonal influx and decomposition of autochthonuous macrophyte litter in a north temperate estuary. Hydrobiologia 71: 197-208

Kenworthy, W. J. (1981). The interrelationship between seagrasses, Zostera marina and Halodule wrightii, and the physical and chemical properties of sediments in a midAtlantic coastal plain estuary near Beaufort, North Carolina (USA). M. S. thesis, Univ, Virginia, Charlottesville

Kenworthy, W. J., Thayer, G. W. (1984). Production and decomposition of the roots and rhizomes of seagrasses, Zostera marina and Thalassia testudinum in temperate and subtropical marine ecosystems. Bull. mar. Sci. 35 (3): 364-379

Marshall, N. (1970). Food transfer through the lower trophic levels in the marine environment. In: Steele, J. H. (ed.), Marine food chains. Univ. California Press, Berkeley, pp. $52-56$

McRoy, C. P., Helfferich, C. (ed.) (1977). Seagrass ecosystems: a scientific perspective. M. Dekker, New York

Menzies, R. J., Rowe, G. T (1969). The distribution and significance of turtle grass Thalassia testudinum on the deep sea floor off North Carolina.

Menzies, R. J., Zaneveld, J. S., Pratt, R. M. (1967). Transported turtle grass as a source of organic enrichment of abyssal sediments off North Carolina. Deep Sea Res. 14: 111-112

Nixon, S. W. (1980). Between coastal marshes and coastal waters - a review of twenty years of speculation and research on the role of salt marshes in estuarine productivity and water chemistry. In: Hamilton, P., Mac Donald, K. B. (ed.) Estuarine and wetland processes. Plenum Publ. Corp., New York, p. 437-525

Ostenfeld, C. H. (1908). On the ecology and distribution of grass wrack (Zostera marina) in Danish waters. Rep. Dan. Biol. Stn 16: 1-62

Penhale, P. A. (1977). Macrophyte-epiphyte biomass and productivity in an eelgrass (Zostera marina L.) community. J. exp. mar. Biol. Ecol. 26: 211-224

Penhale, P. A., Smith, W. O., jr. (1977). Excretion of dissolved organic carbon by eelgrass (Zostera marina) community J. exp. mar. Biol. Ecol. 26: 211-224

Petersen, C. G. J. (1918). The sea bottom and its production of fish food. A survey of the work done in connection with valuation of the Danish waters from 1883-1917. Rep. Dan. Biol. Stn 25: 1-82

Petersen, C. F. J., Boysen-Jensen, P. (1911). Valuation of the sea. I. Animal life of the sea bottom, its food and quantity. Rep. Dan. Biol. Stn 20: 1-81

Tenore, K. R. (1977). Growth of the polychaete, Capitella capitata, cultured on different levels of detritus derived from various sources. Limnol. Oceanogr. 22: 936-941

Thayer, G. W., Wolfe, D. A., Williams, R. B. (1975a). The impact of man on seagrass systems. Am. Scient. 63: 288-296

Thayer, G. W., Adams, S. M., LaCroix, M. W (1975b). Structural and functional aspects of a recently established Zostera marina community. In: Cronin, L. E. (ed.) Estuarine research. Vol. 1. Academic Press, New York, p. 518-540 
Thayer, G. W., Engel, D. W., LaCroix, M. W. (1977). Seasonal distribution and changes in the nutritive quality of living, dead and detrital fractions of Zostera marina L. J. exp. mar Biol., Ecol. 30: 109-127

Thayer, G. W., Kenworthy, W J., Fonseca, M. S. (1984). Ecology of eelgrass meadows of the Atlantic Coast: A community profile. U.S. Fish and Wildl. Serv. Publ. no. FWS/OBS-84/02

Williams, R. B. (1973). Nutrient levels and phytoplankton productivity in the estuary. In: Chabrek, R. H. (ed.) Proceedings of the coastal marsh and estuary management symposium. Louisiana State University, Baton Rouge, p. $58-89$

Wolff, T. (1976). Utilization of seagrass in the deep sea. Aquat. Bot. 2: 161-174
Zieman, J. E. (1975). Quantitative and dynamic aspects of the ecology of turtle grass, Thalassia testudinum. In: Cronin, L. E. (ed.) Estuarine research. Vol. 2. Academic Press, New York, p. 541-562

Zieman, J. C., Thayer, G. W., Robblee, M. B., Zieman, R. T. (1979). Production and export of seagrasses from a tropical bay. In: Proceedings of conference on biological processes in coastal and marsh systems. Plenum Press, New York, p. $21-33$

Zieman, J. C. (1982). The ecology of the seagrasses of South Florida: a community profile. U. S. Fish and Wildl. Serv. Publ. no. FWS/OBS-82/25

This paper was submitted to the editor; it was accepted for printing on October 11, 1985 